This is the accepted version of an article published by Oxford University Press in International Studies Perspectives Vol. 17 No. 4, 445-461, 2016. Published version available from:

Interviews as Catastrophic Encounters: An Object Relations Methodology for IR Research

\title{
JULIA GALLAGHER, Royal Holloway, University of London
}

The article uses psychoanalytic object relations theory to construct a way to understand why interviews in IR research - viewed here as encounters between strangers - can be felt as 'catastrophic'. The theory supports critical theoretical approaches that suggest that the world is structured through self-other relations, and argues that encounters with 'others' are unsettling because they can undermine the ways we constitute ourselves in relation to the wider world. Yet such challenges are inevitable if research is to challenge existing object constructions and the power relations that attend them. The article illustrates this argument with a detailed discussion of research interviews conducted in Zimbabwe.

Key terms: interviews, critical IR, object relations theory, Klein.

This article explores the dynamics of meetings between strangers during interviews in IR research. It begins from a critical approach to IR, one that argues that identity is formed through the creation of an alternative other (Edkins 1999). For feminist and post-colonial critical scholars, the world is structured around binaries: foreign constitutes the domestic, the outsider the insider, the man the woman, the third world the first world, and the stranger constitutes the familiar self. Given this dynamic, interviews - and fieldwork in general - might 
This is the accepted version of an article published by Oxford University Press in International Studies Perspectives Vol. 17 No. 4, 445-461, 2016. Published version available from:

https://doi.org/10.1111/insp.12099

Accepted version downloaded from SOAS Research Online: http://eprints.soas.ac.uk/26058/

provide a profound challenge to the researcher's sense of herself, as well as her understanding of the world (Vrasti 2008). ${ }^{1}$

\section{Introduction}

This issue has arisen for me during a research project on British-Zimbabwean relationships, during which I - a British academic - conducted a series of interviews with Zimbabweans. In the context of the long and messy relationship between Britain and Zimbabwe, each party to the interview had inevitably invested the other with particular characteristics and meanings that help them make sense of the world and of themselves. The relationships established in the interviews therefore played out some of the larger political, historical and social ideas and practices that were the subject of the research. Given their role in how we shape the world and ourselves in relation to it, I assumed they would be difficult to relinquish. What concerned me was how to both use and get past my own creation of the Zimbabwean 'stranger', in order to see how my creation of him and his creation of me might inform the broader research questions. I think my particular problem is one common to much IR research, which might be viewed as a process of approaching the world with particular perspectives, being met by rather different perspectives, and either being unable to let them go making the research process narrow and unrevealing - or seeing them disturbed - potentially catastrophically - by their encounters with the world.

As der Derian points out, post-structuralists do not escape the logic of the selfother relationship, they must simply be aware that it shapes them, and that they cannot but use it to shape the world around them. 'It is not in synthesis but by learning to live with irreconcilable differences and multiple identities - in high theory and in everyday practices - that we might find our best hope for

\footnotetext{
${ }^{1}$ In this article I refer to the researcher as 'she' and the interviewee as 'he' both to distinguish between the two and to reinforce the central theme here of the mutual otherness of the protagonists.
} 
This is the accepted version of an article published by Oxford University Press in International Studies Perspectives Vol. 17 No. 4, 445-461, 2016. Published version available from:

https://doi.org/10.1111/insp.12099

Accepted version downloaded from SOAS Research Online: http://eprints.soas.ac.uk/26058/

international relations' (1990: 296). This article is an attempt to see what 'everyday practices' - in this case a series of interviews between a Briton and Zimbabweans - can enable an exploration of 'irreconcilable differences and multiple identities'. It argues that a closer reading of the interview encounter itself, its dynamics and the ways it expresses emotions and ideas connected to difference, can be a way to explore the way difference shapes IR. And it uses psychoanalytic theories on projection and relationships between objects to unpack why and how people construct themselves through relationships.

I begin with Kristeva's assertion that encounters between strangers have a 'catastrophic' quality. Kristeva describes the 'violent, catastrophic aspect of the encounter with the foreigner', arguing that, 'as test of our astonishment, source of depersonalization, we cannot suppress the symptom that the foreigner provokes; but we simply must come back to it, clear it up, give it the resources our own essential depersonalizations provide' (1991: 190).

The 'stranger', says Kristeva, is an abstract entity, one by which we create and control the world, and one by which we define ourselves. Strangers necessarily have blank faces, they are partial sketches, emanating from, and therefore apparently controlled by, us. The stranger is a receptacle into which we can put our own suppressed unpleasant features, or our self-idealizations. Held comfortably at a distance, within the stranger, we do not need to acknowledge internal ambiguities.

This is what makes the encounter so painful: it forces on us realizations of differences or similarities that do not conform to our preconceptions. Our fears or idealizations projected onto the stranger are not properly reflected back; the imagined solidity of difference, of outsideness becomes obscured. We realize that, as Kristeva points out, the 'foreign' is inside us, while the 'foreigner' is uncontrolled by us. Coming face to face with this uncontrolled reality shakes not only our feeling of understanding the world, but of understanding ourselves. 
This is the accepted version of an article published by Oxford University Press in International Studies Perspectives Vol. 17 No. 4, 445-461, 2016. Published version available from:

https://doi.org/10.1111/insp.12099

Accepted version downloaded from SOAS Research Online: http://eprints.soas.ac.uk/26058/

Such ideas have been widely explored in international political theory. In particular, critical approaches have addressed the ways in which Western, male subjects have constructed a self that is rooted in a constructed alternative 'other' (Fanon 1986; Said 2003; Mudimbe 1988; Butler 2006). And it is why many scholars emphasize re-privileging views from the 'margins' and the importance of fieldwork in research, of problematizing self-other dichotomies by exposing them to solid encounters. Sylvester, who carried out extensive fieldwork in Zimbabwe in the 1990s provides one example of a 'critical feminist epistemology' (1994; 2000), contributing to feminist research methodologies that have been particularly engaged in such questions (see Ackerly, Stern \& True 2006; Ackerly \& True 2010).

Many IR researchers have written about the disturbing, destabilizing aspects of fieldwork particularly in the early stages when the strange is painfully visible (Jackson, 2010) or where there are sharp political or ideological differences between the researcher and those she is researching (Michalowski, 1996; Jacoby, 2006). During fieldwork, says Agar, the researcher enters into an 'encounter with a different point of view' (2006: 15) which puts her off-balance: she must let go of what she thought she knew. The 'strange is made familiar, and the familiar is recognized as strange' (Rancatore 2010: 75). Davies argues that this position presents opportunities for understanding (2010: 3), Crapanzano that it is a 'fertile fact' (2010: 65), while Jackson suggests that 'to understand is to suffer the eclipse of everything you know, all that you have, and all that you are' (2010: 43). For these researchers, the experiences of uncertainty and bewilderment themselves allow the researcher to see things differently.

In contrast to Bourdieu's suggestion that a successful interview minimizes 'symbolic violence' (1996), many researchers describe how the 'catastrophic' aspects of fieldwork can be the most illuminating as they force researchers into a reevaluation not only of their conceptions of the 'other' but of themselves too. An excellent example of this is Parker's discussion of her encounters with female circumcision during fieldwork (on disability and bilharzia) in Sudan (1996). 
This is the accepted version of an article published by Oxford University Press in International Studies Perspectives Vol. 17 No. 4, 445-461, 2016. Published version available from:

https://doi.org/10.1111/insp.12099

Accepted version downloaded from SOAS Research Online: http://eprints.soas.ac.uk/26058/

Horrified by the ceremonies she attends, and troubled by the incomprehension of her feelings by the women who organize them, Parker is forced to reexamine her own prejudices (about the safety of the practice, and its social role in the subjection of women). Parker admits that she never does 'get it' - she and the women she is living with cannot see the practice from each other's perspectives - and her conclusions about different social constructions of femininity and sexuality are consequently surprising and profound. Hers therefore is not an account of encounters that lead to closer mutual understanding, but one which causes her to explore and reevaluate difference.

In this article I explore the nature of encounters between strangers as experienced in interviews conducted as part of IR research. I look closely at the ways the catastrophic elements of the encounter are manifest, and how these shake the preconceptions of both the interviewer and interviewee. In order to do this I build on Kristeva's suggestion, and the fieldwork experiences of researchers, by using the object relations theory of Melanie Klein to flesh out a framework for thinking about what goes on in interviews. Klein's psychoanalytic theory is less well-known to political theory than that of Freud or Lacan, ${ }^{2}$ largely

2 Much has been made of the differences between the analytic schools of Melanie Klein and Jacques Lacan (these were discussed in a series of dialogues between members of the two schools in 1994-5 - see Burgoyne and Sullivan 1997). Both analysts were followers of Freud, and adopted his concern with the tragic nature of human subjectivity (Keylor 2003). In both approaches, infants are dominated by feelings of grief, loss and anxiety caused by the death instinct, which they overcome by creating and mastering symbols to construct meanings of the world around them. In this way loss and anxiety are hidden in the unconscious, while symbolism is used to establish a sense of mastery over the world and the self. For Klein this mastery is constrained by the continuing internal divisions between life and death drives which are universal and innate. However, she holds that the developing child can put split objects together and construct a fragile (never fully complete) ego. For Lacan, the adoption and mastery of 
This is the accepted version of an article published by Oxford University Press in International Studies Perspectives Vol. 17 No. 4, 445-461, 2016. Published version available from:

https://doi.org/10.1111/insp.12099

Accepted version downloaded from SOAS Research Online: http://eprints.soas.ac.uk/26058/

because she rarely pushed it beyond the clinical level. However, it has been taken up by some political and social theorists, including Kristeva (2001), Alford (1989) and Chodorow who argues that Klein provides an 'early source of psychoanalytic feminism' (1989: 3). Her work is instructive for IR researchers because it explores the ways in which subjects constitute themselves through the juxtaposition of their internal objects with the objects they encounter in the external world - a process that resonates with the IR preoccupation with the relation between insideness and outsideness (Walker 1993). Klein's work directly addresses the way we use outsideness to help us construct and protect insideness, and provides a model and a psychological underpinning for the compulsive attractions of the inside/outside binary (Gallagher 2009; 2014).

The article proceeds as follows. The next section provides an account of Klein's object relations theory, and a discussion of how this relates to research in IR. In the following two sections I first describe four interview encounters from my recent research in Zimbabwe; and second discuss what the difficulties encountered in them might mean in terms of the protagonists' conceptions of and engagement with the other. Finally, I conclude with some broader observations about discomfort and catastrophe in IR research.

\section{Object Relations Theory and IR Research}

Klein's object relations theory describes the way a person's ego is constituted through their engagement with the outside world, specifically through the introjection (taking in) of external objects, and the projection of internal objects onto external objects (Klein 1997b). The interaction between introjection and

external laws and linguistic culture - the 'symbolic order' - are what both protect the child from her destructive feelings, and constrain her and alienate her from her own desire. Lacan therefore holds that appearances of coherence are illusory and indicative of a lack of awareness of the unconscious. 
This is the accepted version of an article published by Oxford University Press in International Studies Perspectives Vol. 17 No. 4, 445-461, 2016. Published version available from:

https://doi.org/10.1111/insp.12099

Accepted version downloaded from SOAS Research Online: http://eprints.soas.ac.uk/26058/

projection 'both builds up the internal world and shapes the picture of external reality' (Ibid: 141), and so the two are intimately connected.

Internal objects can be described as 'internal working models', the frameworks and patterns of analysis that both constitute our sense of ourselves, and that we use to help us understand the world (Bowlby 1973). Klein calls the projection of internal objects 'projective identification': 'Identification by projection implies a combination of splitting off parts of the self and projecting them on to (or rather into) another person' (Klein 1997b: 143). In the process, we split the world up into corresponding bits, organizing it within our own pre-determined structures. This trying out of our internally-shaped frameworks in the world, something like a constant assessment of the world within ready-made frames of reference, amounts to a process of making the world in relation to yourself. In turn, their introjecton supports the internal objects, reinforcing a sense of their solidity (Klein 1997a).

During infancy - when the ego is being formed - unbearable aggressive emotions are projected onto external objects in particularly violent ways. Klein argues that infants fantasize about tearing and biting objects into bits (Segal 2006). At the same time, idealized 'good' emotions are projected onto external objects which are experienced as perfectly loving. In this way, the infant creates an ideal world for itself in which 'good' and 'bad' objects are experienced as completely separate. As they develop, children learn to recognize and acknowledge their own aggression and to engage with the world more reflectively. They begin to recognize ambiguity in it - that objects are both good and bad - reflecting and helping them build their own more complex internal objects. The working through of this recognition allows them to make reparative moves towards external objects, and to achieve a sense of repair of the damage they have (in imagination) done to external objects, in part through seeing external objects survive, and thus establishing their separateness, and through introjection to repair and enrich their internal objects. If successfully achieved, this process enables the development of a well-integrated ego capable of accepting its own 
This is the accepted version of an article published by Oxford University Press in International Studies Perspectives Vol. 17 No. 4, 445-461, 2016. Published version available from:

https://doi.org/10.1111/insp.12099

Accepted version downloaded from SOAS Research Online: http://eprints.soas.ac.uk/26058/

aggression, and expressing loving feelings towards others. But it remains a balancing act throughout life as we veer between our internal and external objects which are always juxtaposed, always mutually constitutive, but never quite fitting together.

Projective identification is an aggressive act, but it is also creative one. Winnicott describes the creativity of 'play' - by which he means the ways we imaginatively shape the world, arranging it around fantasies and ideas that originate inside ourselves - and its essential role in developing a sense of self. When we are not constrained by relating to external objects as real and independent, as we are not in play or fantasy, we can arrange them as we like, we give free-rein to our internal objects. 'It is in playing and only in playing that the individual child or adult is able to be creative and to use the whole personality, and it is only in being creative that the individual discovers the self' (Winnicott 1971: 54). Klein would argue that it is in this way that we create and reconnect to ideal objects, and it describes the excitement of creativity which is connected to the glamor of idealization. When we leave play and fantasy behind in our engagement with the real world, we confront the loss of the ideal, leading to feelings of despair and loneliness (Klein 1997c: 305).

Thus we have a connection between projection, aggression, creativity and egoformation, coupled with the sobering effects of confronting the separate outside world. I think this is a useful way to understand the research process. It is possible to see how the researcher's internal objects - theories - are used to 'split' the world up and organize it so as to bring order to external objects that otherwise would exist in a state of unruly chaos. It is also possible to use Klein's theory to explore the creative potential of doing this, its essential role in helping us establish a sense of who we are, and also the excitement and glamor of exercising imagination and creativity.

If we understand research through the lens of object relations theory, we might conceive of two dangers that work in different ways to undermine its quality. 
This is the accepted version of an article published by Oxford University Press in International Studies Perspectives Vol. 17 No. 4, 445-461, 2016. Published version available from:

https://doi.org/10.1111/insp.12099

Accepted version downloaded from SOAS Research Online: http://eprints.soas.ac.uk/26058/

The first is anxiety about its aggressiveness. In extreme cases, Klein argues, the fear of damaging external (and thereby internal) objects causes a person to refuse to engage in acts of creativity, because of the overwhelming fear that objects that we 'chop' up will collapse completely. She described examples of patients who are so overwhelmed with their own aggressive feelings that they fail to develop the ability to speak properly, or to read and write, to master activities that demand the imposition of artificial systems onto the world (Klein 1998b). She explains this in terms of the violence done by using words which tear the world to bits, categorizing and spoiling it. Words force us to confront the separateness of the world from ourselves (its non-ideal status) and our own aggressive feelings about it (1998a). This is an existential fear and it underlines the inter-relatedness between the external and internal objects: damage done to one can be felt to destroy the other.

Perhaps this can be used to explain the fear of sitting down to write, to decide on a scheme of organization, that nearly all researchers experience at some point. But it also might be seen in overly descriptive work that minimizes the 'chopping' done by the researcher. 'Chopping' is an aggressive, creative act: it requires us to draw patterns and make inferences by shaping the world into schemes of our own choosing. But it does violence to a reality that it never captures properly, distorting and destroying alternative arrangements, asserting mastery and ownership. One defense against aggressiveness might be a refusal to engage creatively with the world.

The second danger is an overly aggressive use of theory, a 'chopping' that forces external objects into categories and fails to acknowledge that they (inevitably) do not fit properly. Alford, drawing on the work of Habermas, calls this 'instrumental reason', a reason used to arrange the world to fit existing preconceptions (1989). He argues that instrumental reason inhibits an engagement with the world as separate, causing us to bend the world to fit, refusing to see external objects as anything other than exact copies of our internal objects. Alford points to theory that attempts to transcend particularism, 
This is the accepted version of an article published by Oxford University Press in International Studies Perspectives Vol. 17 No. 4, 445-461, 2016. Published version available from:

https://doi.org/10.1111/insp.12099

Accepted version downloaded from SOAS Research Online: http://eprints.soas.ac.uk/26058/

because ideal, as likely to lead to overly rigid symbolism, in which external objects are imagined to be identical to internal objects. He explores alternative approaches that are more contingent and flexible, rooted in their situation, as allowing an exploration of external objects through their 'fit' into internallycreated systems, but still allowing those systems to be challenged and altered through the encounter. Drawing on Klein, he calls this 'reparative reason', which, although not devoid of aggressive intent, manages to integrate it with a concern for the object and a desire to understand it on its own terms. ${ }^{3}$

Researchers often encounter the dangers of rigid symbolism in the early stages of research when a first, cursory glance at the world appears to confirm our theories. Many times I have optimistically set out on a piece of research imagining that this one will be quickly and efficiently dispatched, only to find myself bogged down in chaos, my theory blown to bits by what I have read and found. Again, this approach can persist to the end of a piece of research, and is sometimes seen in overly tidy, schematized work, where case studies have been chosen for their perfect fit to theory, or a theory is employed over and over again, apparently able to explain everything, undisturbed by facts that refuse to fit. This is another defense, this time against internal ambiguity. If the world's objects provide a perfect fit, they do not disturb our internal objects, we are confirmed in our self-certainty.

Engaging with and trying to understand the world is a difficult and risky business. We constantly attempt to find a balance between chopping the world into pieces to fit a model or theory (a necessary part of creativity and selfrealization); and allowing for the fact that our model or theory is flawed and conditional - and that we will probably have to do it differently tomorrow. We have to learn to live in the highly uncomfortable position of 'knowing' and not

\footnotetext{
${ }^{3}$ Alford draws on Gilligan's work on alternatives to universalistic 'moral reasoning' - in particular reasoning from a perspective of care - as an example of 'reparative reason' (Alford 1989: 163-9).
} 
This is the accepted version of an article published by Oxford University Press in International Studies Perspectives Vol. 17 No. 4, 445-461, 2016. Published version available from:

https://doi.org/10.1111/insp.12099

Accepted version downloaded from SOAS Research Online: http://eprints.soas.ac.uk/26058/

knowing.

It is this uncomfortable position that Kristeva describes as 'psychic discomfort' (2001). Confronting the stranger - an external object that we wish to fit into the patterns created by our internal objects - we must acknowledge his refusal to fit, and the consequent damage this does to our sense of grip on the world, and sense of ourselves. Being researchers we have already put ourselves into the world, given ourselves the job of chopping it up into bits. If we are not overly rigid in the way we do this, then inevitably, the catastrophic nature of our confrontations must be deeply unsettling.

I hope this exposition of a theoretical underpinning can do two things. First, provide a way to understand and reinforce what many researchers already know: that being unsettled in the field potentially makes the researcher more vulnerable to new ways of constructing the world, in other words, for understanding it better. The element of being 'unsettled' relates to the disturbance done to internal objects - ways of seeing and understanding the world - by encounters with external objects. The researcher arriving in the field has (consciously or not) constructed a version of what she is researching. If such a theory is to be 'flexible', she needs to allow it to be challenged or destroyed and to find ways to reconstruct it differently. Drawing on Klein, this is not just a challenge to the authority and knowledge of the researcher, but profoundly to her sense of self.

Building on this, I suggest that attempts to establish rapport, or to 'step into the lifeworld' of the people being interviewed can be a way of defending against such challenges. These are manifest in the idea that the disjuncture between the interviewer and interviewee should be overcome as quickly as possible (and many researchers describe the strategies they use to attempt to do this - Glesne \& Peshkin 1992; Ellis \& Berger 2003; Fontana \& Frey 2005; D’Costa 2006; Ezzy 2010). But a profound engagement with something that truly unsettles internal objects is difficult and will involve significant discomfort. My concern is that a 
This is the accepted version of an article published by Oxford University Press in International Studies Perspectives Vol. 17 No. 4, 445-461, 2016. Published version available from:

https://doi.org/10.1111/insp.12099

Accepted version downloaded from SOAS Research Online: http://eprints.soas.ac.uk/26058/

too-quick resolution of discomfort might lead to a denial of the damage done by the encounter to internal objects, and thus less need to remake them. It is easy to see why this might be something the researcher is tempted to do; but it is also possible to see why it is important for them to resist doing it.

Second, Klein's theory can help us to explore what the interviewee is experiencing, and this might help enrich our work. He too, arrives at the interview with preconceptions and theories about the world and the researcher. These may become apparent in the course of the interview. Whether they are challenged in the interview or not, it should be possible for the sensitive researcher to become aware of the ways in which the interviewee constructs the world, partly through the way he constructs the interview, and also how this relates to his constructions of himself. Often an awareness of this emerges in the interviewer's own feelings about the relationship developing in the interview, experienced because of the way in which the interviewee projects his feelings and understandings onto her. In order to illustrate and extend these ideas, I now turn to a discussion of some of the interviews I conducted during fieldwork in Zimbabwe.

\section{A British Researcher in Zimbabwe}

I conducted fieldwork in Zimbabwe in a series of visits in 2011, 2012 and 2013, part of a project on African conceptions of the international and how these relate to questions of state identity - a corollary of the way relationships with external objects shape internal objects. One focus within this very broad topic is to explore Zimbabwean conceptions of the relationship between Zimbabwe and Britain. Within a complex and long history, the triangle of relationships between Zimbabweans, their state and Britain have challenged and constituted 
This is the accepted version of an article published by Oxford University Press in International Studies Perspectives Vol. 17 No. 4, 445-461, 2016. Published version available from:

https://doi.org/10.1111/insp.12099

Accepted version downloaded from SOAS Research Online: http://eprints.soas.ac.uk/26058/

Zimbabwean subjects in various, and often conflicting ways. ${ }^{4}$ I aim to explore how the dynamics of these relationships work in my interviews with Zimbabweans. To date I have conducted interviews with more than 150 people living in or near the country's two main cities, Harare and Bulawayo. Early interviewees were local NGO activists, representatives of residents' associations or political activists; increasingly, through these groups, I was able to meet and interview less politically active residents. Roughly half of these interviews were conducted one-to-one, and the rest in groups of between two and 15 people. Most were conducted in English, while others were done in a mixture of English, Shona and Ndebele with help from a translator.

Following Ackerly and True's injunction that a thoughtful approach to research

4 Zimbabwe was conquered by the British in the late $19^{\text {th }}$ century, and declared independent by a white minority government in 1965 under the Unilateral Declaration of Independence (UDI). There followed a protracted and violent struggle for majority rule during the 1960s and 1970s, a struggle that Britain was unable or unwilling to prevent (Watts 2005). The independence agreement, brokered by Britain in 1979 at Lancaster House, has remained contentious, as it left important issues such as land reform deliberately hazy (Chan 2003; Mtisi, Nyakudya \& Barnes 2009). As Zimbabwe's international standing declined from 2000, the relationship with Britain in particular has descended into insult and name-calling on both sides. British aid was cut back, diplomatic relations scaled down, sanctions imposed on members of the government and efforts made to isolate the country within the international community. Mugabe frequently fingered Britain as the cause of Zimbabwe's ills, and in doing so has tapped into significant grievances among Zimbabweans (Tendi 2010). Zimbabwe remains exceptional in its relationship with Britain, by its refusal to fit into British conceptions of itself as a positive and helpful friend to Africa, and the continual efforts of its leaders to revive painful memories of colonialism and their rejection of British conceptions of itself as a force for good in the continent (Gallagher 2011). 
This is the accepted version of an article published by Oxford University Press in International Studies Perspectives Vol. 17 No. 4, 445-461, 2016. Published version available from:

https://doi.org/10.1111/insp.12099

Accepted version downloaded from SOAS Research Online: http://eprints.soas.ac.uk/26058/

is one that involves an attentiveness to the researcher's 'social, political, and economic relationships' with those she is researching, it is important to acknowledge the way one positions oneself within the study (2010: 37). Zimbabwe plays a powerful part in my identity, derived from both a sense of intimacy and sympathy, and of alienation and fear of the country. Among other influences, I had had a childhood interest in southern Africa instilled in me by my exiled South African mother, experience of working in Zimbabwe as a teacher in the early 1990s, and then years of absence shaped by fantasies of the destruction wrought by AIDS and economic decline, along with exposure to negative news stories about the country and its president, discussions with various Zimbabwean friends, an admiration for the novels of Yvonne Vera, and my own academic study of the soured relationship between the governments of Britain and Zimbabwe. My starting position for the study was one of ambivalence as to my status as an insider or an outsider.

This confusion of feeling resonates with wider British understandings of Zimbabwe and its long and often tortuous colonial and postcolonial relationship. The British government itself had followed a trajectory of rejection of Ian Smith's Unilateral Declaration of Independence (UDI) in 1965, reengagement at the introduction of majority rule in 1980 and warm support for President Robert Mugabe that soured during Tony Blair's premiership, worsened at the appropriation of land from white farmers, and eventually led to Zimbabwe's suspension (and resignation) from the Commonwealth, sanctions against members of the government, and an 'extraordinary' shouting match between government ministers on both sides (Chan 2003: 152). The British media's often hysterical fascination with Zimbabwe feeds British people with stories of distress, fear and horror at its economic and political collapse, and incomprehension at Mugabe's apparent metamorphosis from freedom fighter into monster. ${ }^{5}$

\footnotetext{
${ }^{5}$ For just a few examples of British media coverage of Zimbabwe from the BBC, Daily Mail and Daily Telegraph respectively, see:
} 
This is the accepted version of an article published by Oxford University Press in International Studies Perspectives Vol. 17 No. 4, 445-461, 2016. Published version available from:

https://doi.org/10.1111/insp.12099

Accepted version downloaded from SOAS Research Online: http://eprints.soas.ac.uk/26058/

Given this highly implicated history, the relationship between Britons and Zimbabweans is significant to the sense each has of itself and itself in the world. In important ways, each side informs the other's selfhood. I think this is true for many of us - even those who have never visited or met the other. The idea of 'Britain', and the idea of 'Zimbabwe' are powerful components of our imagination of the wider world, one that is both distant, but apparently familiar. These ideas allow, as Winnicott suggests, opportunities for imaginative play and fantasy, helping us construct a sense of self.

One of my key concerns is how is this sense of self in relation to other expressed in physical encounters, and what happens to it as a result. I will describe key elements of four interview encounters. An analysis of each follows in the next section.

The first is an interview with a group of eight people (seven men and one woman who alone remained silent) from an urban residents' association. ${ }^{6}$ I had made contact with the chairman at the suggestion of an NGO activist I had interviewed on a previous visit, and had set the meeting up by email. The meeting took place at my guesthouse. As they arrived, the chairman, a large, laughing, ebullient man, embraced me warmly. He congratulated me on organizing a room (complete with a clothed table, jugs of water and glasses) for our interview. 'I wish we could have people with your powers of organization working for us!'

http://news.bbc.co.uk/1/hi/world/africa/807061.stm [cited, 24 January 2012]; http://www.dailymail.co.uk/debate/columnists/article-443104/Ian-Smithright-.html [cited, 24 January 2012]; and http://www.telegraph.co.uk/culture/books/non fictionreviews/3555293/Robe rt-Mugabe-lonely-monster.html [cited, 27 January 2012].

${ }^{6}$ Interview, 30 May 2012. In order to anonymize the individuals involved, I have not used the name of the group or its location. 
This is the accepted version of an article published by Oxford University Press in International Studies Perspectives Vol. 17 No. 4, 445-461, 2016. Published version available from:

https://doi.org/10.1111/insp.12099

Accepted version downloaded from SOAS Research Online: http://eprints.soas.ac.uk/26058/

I opened with my usual question: how was life in Zimbabwe? They began to talk about the 'natural problems' that the country faced - drought, AIDS, the global recession. 'But our government at all times, it has never folded its hands.'

The discussion turned to British-led sanctions which were, they said, the source of Zimbabwe's economic and political problems. After talking on a general level for a while, as if exploring the problems of a third party together, I suddenly found myself being addressed very directly by the oldest, male member of the group:

When you talk about sanctions, the former colonizer was not fair. They were targeting politicians, but the majority of the people are not politicians. But they knew exactly what would happen. There are a lot of problems. You are coming from a country with these laws and acts. You are sitting next to people who are putting screws on Zimbabwe. The country is almost at a standstill and all those problems are caused by sanctions. Are there no other ways to speak to Zimbabweans? We could have said we don't want to speak to anyone from Britain. But we are very open. Are there no other ways of speaking politics to us without hurting people outside politics? Why have you thought we must tighten these screws? Why did you want to kill the child coming from the womb? You wanted to discuss a very hot potato. These are the types of politics that are very unfair. The colonizers choose to close this country. Why do you want to put the politics here?

I was surprised and slightly panicked by the outburst: it is unusual for people to be so direct or so critical, and the comments seemed to be a direct attack. There was a long pause. Then another member of the group said: 'We are expressing the feelings of the people out there.' I asked if there was a lot of anger towards Britain, at which several members of the group began to stress that it was concern, not anger; or anger at the British government not the British people. And the discussion moved back to the third party again, remaining with the same 
This is the accepted version of an article published by Oxford University Press in International Studies Perspectives Vol. 17 No. 4, 445-461, 2016. Published version available from:

https://doi.org/10.1111/insp.12099

Accepted version downloaded from SOAS Research Online: http://eprints.soas.ac.uk/26058/

theme of British cruelty, but without the direct confrontation. At the very end one of the group remarked: 'We do not see you as British - you are one of us.'

The second example involves my meeting with a group of 15 traders - men and women - from across the country who had gathered for a training session in an office in Harare. ${ }^{7}$ We all sat around a large table together, me at one end, with most of the 15 arranged along the long sides facing each other. They told me that, with the collapse of the economy, Zimbabwe's informal sector has become the only way for most people to make a living, mainly by buying goods from neighboring countries or Chinese traders and selling them in established markets (if they can get a site) and on street corners. Informal livelihoods are constrained by restrictive by-laws, by local ruling-party-controlled vending sites and by police corruption. One of the informal workers' chief complaints is that the government has failed to recognize the sector. As a result, a difficult way to make a living is made harder: 'Every effort is being stifled... What we are doing is to fight the system. We want regulation.'

For a while the discussion focused on the contrast between a restrictive state and the informal workers who cope and organize themselves.

Zimbabweans are very, very enterprising. Some of this capital, we get it from friends and family. Then we pay back and get some money to go back [to South Africa, Zambia or Botswana] again. We can't get access to cash at the bank.

I've been going to South Africa to buy blankets, DVDs and televisions but it's becoming increasingly difficult. Duty has increased.

\footnotetext{
${ }^{7}$ Interview conducted in Harare, 6 September 2011.
} 
This is the accepted version of an article published by Oxford University Press in International Studies Perspectives Vol. 17 No. 4, 445-461, 2016. Published version available from:

https://doi.org/10.1111/insp.12099

Accepted version downloaded from SOAS Research Online: http://eprints.soas.ac.uk/26058/

Most people join together, like four or five people buying from Japan, but only one will go. One goes and comes back, with shoes, clothing, food, maybe furniture.

The major problem is how to get goods into Zimbabwe. The police will come and get everything because I don't have permission to sell...

...along with the Zimra Control [the tax authorities] who can take all your property.

Sometimes when I try to sell the local goods from the supermarkets to the rural area, the police will come and collect all.

There's a certain perception of the informal sector - we are the people. Wherever they see people at Mbare - when you get there, you think there is disorder, but actually there's a protocol, a leadership, a structure. But unfortunately the technocrats and academics are blind. This is a proper, perfectly functioning community. There's a huge separation - we become marginalized.

The discussion was by this time almost entirely unprompted. Members of the group were not unconscious of me, but they maintained the discussion amongst themselves: I was obviously there listening and taking notes, but I was mostly silent. In exploring the question of the Anglo-Zimbabwe relationship, one of the group made a statement:

Let's start from 1980. After the war of liberation, the situation was OK and Britain recognized the government of Zimbabwe as legitimate up until those years which had been agreed at Lancaster House. But during those early years, there was a shift of policy and relationship, whereby the policies were shifted to give the impression that blacks could not rule themselves. People were meant to construe that the black government was 
This is the accepted version of an article published by Oxford University Press in International Studies Perspectives Vol. 17 No. 4, 445-461, 2016. Published version available from:

https://doi.org/10.1111/insp.12099

Accepted version downloaded from SOAS Research Online: http://eprints.soas.ac.uk/26058/

not able to rule them. ESAP was made from Bretton Woods. ${ }^{8}$ People suffered and British companies that were there withdrew. We were looking for these companies to support the government of the day. In 1999, there was the introduction of farm invasion and grabbing. This policy was meant to redress land distribution so that the black majority could get land because most of us had no land. But Britain didn't support our government to land distribution. Instead, they brought sanctions. We do not see sanctions as a main issue but the leaders who were in government could oppress and punish us because of those sanctions. It was an excuse for not providing services. Britain should compensate Zimbabweans for the suffering they are causing. From 1890-1980, Britain should compensate Zimbabweans for taking Zimbabwe's resources to Britain. We feel they should plough something back. They should not feel they should disown us.

This speech was greeted with enthusiastic applause. Then another member of the group said:

The Harare government and the UK government are cohorts in terms of oppressing the people of this country. The policies put in place by Ian Smith - they are still in existence and used by the government to oppress the people they have claimed to fight for. The British left this legacy. To me, if we are not clever, even [despite] our war to change the government, we will still remain with the same problem. You can change the people but leave the systems in place.

This comment was greeted with approving comments. At the end of the session, the workshop organizer asked for a vote of thanks for my visit. There was silence. Afterwards, in a one-to-one discussion with another organizer, I

\footnotetext{
8 ESAP refers to the Economic Structural Adjustment Program, introduced under the auspices of the World Bank and International Monetary Fund in 1992, and generally perceived to have worsened Zimbabwe's economic performance.
} 
This is the accepted version of an article published by Oxford University Press in International Studies Perspectives Vol. 17 No. 4, 445-461, 2016. Published version available from:

https://doi.org/10.1111/insp.12099

Accepted version downloaded from SOAS Research Online: http://eprints.soas.ac.uk/26058/

suggested that they were angry: 'They did not want to thank me.' She replied: 'That is because they think Britain has abandoned them - they were angry with you for that.'

The third example is an interview with two young men who live in Chitungwiza, a large high-density area that is home to some six million people, $30 \mathrm{~km}$ south of Harare. ${ }^{9}$ We met in the home of my main contact in the area, the three of us sitting in large soft armchairs in his rather dark sitting room. Tafawadza is 30 and Musiiwa is 29. They appeared to be drunk, their speech and movements slurred. Tafawadza did most of the talking, constantly leaning very closely to talk to me. Musiiwa sat a little further apart, stroking a bottle of beer and smiling at what his friend said. When I asked them about the history of Zimbabwe, Tafawadza immediately replied: 'From when I can know, the whites like you, they came to colonize us.'

Both men were born after independence, and Tafawadza remembered good early days:

We were used to milk being delivered at the door, bread, the guy who was selling bread, he used to go round on a cycle. Newspapers, we used to get them at the gate. But not now. Right now we have to share [pointing at the bottle of beer], we have to share because the money is hard to get. Morning, you wake up, the time you open your eyes you think where am I going to get money for bread? Then you get money for bread, you think, where is money for lunch? Here in Zimbabwe, we do not have lunch. Grade one to seven, it was free from 1980. It was great then because our mothers were looking after us. But now we cannot leave home. We are supposed to be independent. It was not like that. Our sisters go that side and get babies and then they just come back. At my home I've got cousins, these guys can catch

\footnotetext{
${ }^{9}$ Interview conducted in Chitungwiza, 4 September 2011. The interviewees' names have been changed.
} 
This is the accepted version of an article published by Oxford University Press in International Studies Perspectives Vol. 17 No. 4, 445-461, 2016. Published version available from:

https://doi.org/10.1111/insp.12099

Accepted version downloaded from SOAS Research Online: http://eprints.soas.ac.uk/26058/

my sister and give her a baby. So we have these children. So then, one house, 15 people.

The discussion moved onto politics:

I think politicians are not supposed to be around. They [act like] heroes in front of us. We are supposed to govern ourselves. This guy [pointing at Musiiwa] is a survivor. Have you ever, for one day in your life, worried about food? That's all we worry about. How can I worry about my jeans, my fridge? All my life has been about survival and trying to make my family happy or myself happy... Way back, that's when the story started. Why did the British colonize us? They were killing us. I don't like it. That's what I was reading. Now, is it a helping hand which you people are giving us - is it genuine - or are you just trying to give us a sweet to stop crying? I think I am more educated than you. I am a loafer. I went to school. I was doing Cambridge. I got six As and two Bs. Since I'm born in the hood, you know what I did? I didn't have the money for 'A' levels. When I say different, I mean very, very different.

I found the interview more and more uncomfortable, becoming very aware of the fact that I was alone with these two young men, and I was glad to finish it.

My final example is of an interview with Rose, a 64-year-old woman who lives in Mbare, a slum area of Harare. ${ }^{10}$ We met in the tiny office of an NGO that she was visiting to discuss problems with her accommodation. She began by describing her life:

I've got seven children. We live in the same house with my children, sisterin-law and brother-in-law... The way we live we have no happiness, there's

\footnotetext{
${ }^{10}$ Interview conducted in Harare, 1 September 2011. The interviewee's name has been changed.
} 
This is the accepted version of an article published by Oxford University Press in International Studies Perspectives Vol. 17 No. 4, 445-461, 2016. Published version available from:

https://doi.org/10.1111/insp.12099

Accepted version downloaded from SOAS Research Online: http://eprints.soas.ac.uk/26058/

no freedom. We live in one room with all our children, daughters-in-law and grandchildren. When friends and relatives want to visit us they see us in one room; that we are suffering. Now school is beginning again we do not have money for school fees. We do not have money for medicine. I don't have access for finances to pay for medical bills... There's no electricity most of the time, the toilets are broken down most of the time, sewage flows, there's air pollution which affects people's health. We face serious problems in our lives. Everywhere we walk around there are problems everywhere, as if this is not our country of birth. If the government could build houses for us we could have decent accommodation; most of the diseases are being caused by excessive over-crowding... Since this government came into office there is no time we have enjoyed our freedoms.

I asked her to describe the relationship between Britain and Zimbabwe.

With this issue of sanctions, they must remain in force because if they are removed with this government in office the situation will get worse. Nothing has changed, we are being told lies all the time. All throughout the years, nothing has been transformed so the sanctions must stay. Of course, sanctions can cause problems among the people, but they must remain now because otherwise the situation will get worse. Remove them when there is a new government in office.

As the interview drew to a close I asked her if she had any questions for me. She leaned forward and said:

We thank God for the time He has given us. We are thankful for this opportunity to meet you and talk about these issues because we are really bitter and angry inside. We thank you and God bless you for leading you to come to Zimbabwe. Zimbabweans are suffering. We hope that you help us with guidance from God. 
This is the accepted version of an article published by Oxford University Press in International Studies Perspectives Vol. 17 No. 4, 445-461, 2016. Published version available from:

https://doi.org/10.1111/insp.12099

Accepted version downloaded from SOAS Research Online: http://eprints.soas.ac.uk/26058/

\section{Exploring Catastrophe}

One of the most striking features in these encounters is the way in which the people I interviewed positioned me as an insider or outsider. In this section I analyze the interviews by thinking about this positioning, my reactions to it, and what it might reveal both about Zimbabwean subjectivity and the BritainZimbabwe relationship.

In my first example, the residents' chairman immediately establishes my insideness - we embrace like old friends or family members, he approves of my organizational capacities. I am praised; I could be a member of the group. This makes me feel pleased but also slightly put in my place: the rapport established between this group of older black men and me, a younger white foreign woman, appears to be based on my junior status. Perhaps it arises from the awkwardness of having the meeting at my place, the stranger is acting the host. This ambiguity over who is in charge raises anxiety over who is the insider and who the outsider in this encounter. An uneasy discussion begins in which members of the group describe a series of 'natural' disasters that have befallen the country. I feel they are skirting around a problem - surely we all know who is to blame? But while I feel they are avoiding mentioning the government, it turns out they are avoiding direct mention of Britain and Zimbabwe. When I raise the question of the relationship, it appears to be the issue that is on their minds. I am - Britain is violently pushed out in the critical intervention of the oldest member of the group: I become the person who is 'tightening the screws' who is 'killing the child coming from the womb', the person who does not know how to speak to Zimbabweans. I feel strongly that, having been enfolded into the group at the beginning, I have suddenly been spat out again, a repudiated daughter. The violence of this moment is clearly felt by the whole group. Other members attempt to qualify the comment; the discussion calms down. At the end there is an attempt to rehabilitate my insideness - I am not British at all! 
This is the accepted version of an article published by Oxford University Press in International Studies Perspectives Vol. 17 No. 4, 445-461, 2016. Published version available from:

https://doi.org/10.1111/insp.12099

Accepted version downloaded from SOAS Research Online: http://eprints.soas.ac.uk/26058/

I feel wrong-footed; I have misjudged the group and the relationship. I suspect that part of the problem is that both sides arrived assuming they had the upper hand in the relationship. I have been put in my place. I am no insider after all. They appear disturbed too by the ferocity of the attack. Reparative moves are made: they try to pull me back inside, although I feel that we cannot recapture that initial moment of warmth. I am left wondering whether they both wish for and fear the rejection of Britain: their attitude to me is has been a series of extreme positionings, from the hug, to the angry outburst, to the attempted rehabilitation, although now purely on a personal level: I am Zimbabwean, Britain remains the outsider.

In the second encounter I appear to be more firmly cast as an outsider, but here I feel I am connected to the oppressive government. This group of traders had gathered from around the country for a training workshop. They had developed a strong rapport with each other, and I arrive unexpectedly at the end of their session. The discussion flows freely between them - they exchange views on my few questions rather than answering me directly, aware of me, but apparently uninterested. I feel marginalized; certainly not an insider. I sit on the edge of the group taking notes. They emphasize the organizational capacity and self-reliance among informal workers who, without official help, and without recognition from 'blind' technocrats (in government?) and academics (me?), make a life for themselves. The speech about the litany of British bad faith is greeted by applause. At this point I suddenly feel exposed, like a villain unmasked. Once again there is a strong feeling that the root of the problem - Britain - has been sitting quietly in the corner all the time. This is reinforced by a follow-up comment that links the British and Zimbabwean governments together, 'cohorts' in oppression. I am identified alongside the 'oppressive' Zimbabwean government; in as much as I am an insider, it is there, part of the corrosive heart of Zimbabwean politics that has created so much hardship. 
This is the accepted version of an article published by Oxford University Press in International Studies Perspectives Vol. 17 No. 4, 445-461, 2016. Published version available from:

https://doi.org/10.1111/insp.12099

Accepted version downloaded from SOAS Research Online: http://eprints.soas.ac.uk/26058/

At the end they refuse to extend the usual courtesy of thanking me - instead there is a silence. There is no attempt at rehabilitation: I have been excluded, marginalized; I feel irrelevant. This was interpreted by an organizer as anger at their feeling of having been abandoned by the British - the insiders who had made themselves into outsiders.

This theme of marginalization is continued in my discussion with the two young men in Chitungwiza. Their comments are full of references to parenting: the good parental and governmental provision of their early lives, when bread and milk were delivered to the door, contrasted with stories of hunger and abandonment now. The politicians 'act like heroes' but don't hang around; I am too worried about my jeans and my fridge to do more than offer them a 'sweet to stop crying' - the bad mother? They feel their chances of making a valuable life slipping away from them, their qualifications going to waste, their families impoverished and degraded. Now the cycle is reinforced as their sisters bring fatherless babies into an over-crowded home. They, like their country, were supposed to grow up and become independent. Instead they are infantilized, marginalized and increasingly overwhelmed by more abandoned children.

Their depiction of me as the bad mother is conflated with their sense of a bad government, their own bad parent. I feel this particularly strongly, aware that they are roughly the same age as the Zimbabwean children I taught in the early 1990s, when I was part of the newly independent government's drive to provide universal education. I feel part of that betrayal. They frighten me, give me a taste of what it feels like. The domestic setting of the interview also underlines our intimacy: I feel there is nowhere to hide from these powerful, angry men. Tafawadza rightly points out that his school grades are better than mine. I feel dismissed, physically and morally small. They have seen through me. The interview ends abruptly - I don't want to continue it; I don't want them and their painful sense of abandonment. 
This is the accepted version of an article published by Oxford University Press in International Studies Perspectives Vol. 17 No. 4, 445-461, 2016. Published version available from:

https://doi.org/10.1111/insp.12099

Accepted version downloaded from SOAS Research Online: http://eprints.soas.ac.uk/26058/

Both these interviews leave me with a much stronger sense of rejection, but whereas in the encounter with the traders I feel excluded from an admirable and self-sufficient club, and I leave with feelings of envy and loneliness, in my meeting with the two young men, I feel that I am running away from a violent and vengeful other-world. (I wondered afterwards if they were really drunk or whether my vulnerability made me feel they were out of control.) Both give me ideas about the damage done to Zimbabweans' sense of themselves and their country by the relationship; and also my own wish to be part of the struggle, coupled with a sense that I am complicit in their oppression. Each points to a strong sense of attachment and betrayal that highlight a relationship that is seen from Zimbabwe as intense and current. Britain seems both 'inside' Zimbabwean life, in a corrosive and problematic way, and disengaged, neglectfully outside.

In these three encounters, my outsideness was often made clear, but so too was the sense of my complicity and deep involvement in Zimbabwe. In several of the encounters, I was pulled in, made to feel part of the messy, difficult lives of the people I was interviewing. They both projected their own sense of marginalization onto me, and forced me to confront my own implication in their suffering. Being an insider was being part of a thicker, far less comfortable realm than I had imagined.

Contrasting with these tense moments was the far more common experience where an apparently warm and unproblematic relationship was established in interviews. The fourth encounter with Rose is an example. Her description of life assumed an immediate sympathy between us. Rose told me a story, which I heard over and over again, in which her attempt to live a decent life, in which her children can go to school, she can get reasonable healthcare, sanitary living conditions - happiness and freedom - are undermined by a bad government. These things seem to represent a familiar litany of what a respectable life is. I can understand this: her needs and desires are instantly familiar. 
This is the accepted version of an article published by Oxford University Press in International Studies Perspectives Vol. 17 No. 4, 445-461, 2016. Published version available from:

https://doi.org/10.1111/insp.12099

Accepted version downloaded from SOAS Research Online: http://eprints.soas.ac.uk/26058/

This sense of immediate understanding is reinforced by Rose's comments on sanctions, which, even if they cause problems among the people, are a sign of understanding on the part of the British government. This understanding is contrasted with the 'lies' of the Zimbabwean government. At the end Rose is warmly grateful; her connection of my presence to God's will is flattering. In the face of other, more hostile encounters, I am left with the feeling that we have made a connection: she has shared an intimate account of her life and she has paid me the compliment of speaking openly about a politically sensitive subject, that of sanctions which are directed by my government against hers. It appears that my government and I understand her better than her own. Overall, this feels like a moment of empathy and of insideness.

Reflecting on the interview later though, I see that Rose and I have become involved in a mutual idealization in a way that underlines rather than removes our mutual outsideness. Rose treats me like a savior, someone actually that is not at all implicated in her messy, difficult life. This is perhaps most clear in her final thanks to God for my visit. Inside there is 'bitterness and anger', lies are told all the time, but I am represented as something like a gift from God, untouched by the squalor of life in Zimbabwe - no insider at all. ${ }^{11}$

Moreover, while warm encounters like these feel very safe and comfortable in the moment, after a series of them I begin to feel irritable and uneasy. Their revelations sound rehearsed - the connections too easy, less meaningful - I suspect that people are telling me what I want to hear, or nagging me to come and rescue them. The coziness becomes cloying and manipulative. It is as if the 'inside' represented to me is a concoction, a story told for external consumption. Instead of being part of this story, I am actually pushed away by it, given a 'for export' version. Rose and I have constructed a far thinner and idealized relationship.

11 Thanks to Laura Routley for this observation. 
This is the accepted version of an article published by Oxford University Press in International Studies Perspectives Vol. 17 No. 4, 445-461, 2016. Published version available from:

https://doi.org/10.1111/insp.12099

Accepted version downloaded from SOAS Research Online: http://eprints.soas.ac.uk/26058/

\section{Conclusion}

The inside/outside established in these interviews represents my - and Britain's - relation to Zimbabwe. I want to suggest, however, that largely both positions given to and felt by me result from the way the people I am interviewing create me for themselves with reference to their internal objects. Instances of my 'insideness' are sometimes ideal - the good organizer and colleague, the person who understands Zimbabweans' problems - and sometimes horrible - the creator of repressive laws, the bad mother. Likewise, instances of outsideness are sometimes ideal - when I am 'from God' - and sometimes aggressive and violent - the killer of children. In all of these examples, I am being 'othered', imagined and related to in terms of my interlocutors' 'internal working models' that enable them to shape an understanding of themselves and their country in relation to the wider world. It is as though the people I talk to construct and use me to embody the objects around them - those in the wider world, and those close to home, including themselves and their government. By examining my emotional reactions to these positionings, I feel I can better see what their theories of the world, and their own place in it, are about.

At the same time, I am confronted by my own creations: the avuncular residents' chairman, the self-sufficient and admirable traders, the vengeful, potentially violent youths, the sympathetic, grateful grandmother. My sense of being at home in Zimbabwe is constantly challenged in these encounters as I realize that I do not control these objects, and they continually fail to conform to my understanding of them.

One of the most important realizations that comes from these interviews is the unlikelihood of realizing more nuanced relationships, of recognition. Only one instance here - the first interview with the residents' association - provides I think any evidence of a thickening of the relationship. In this example there is some sense on both sides of the catastrophic nature of the encounter, and both 
This is the accepted version of an article published by Oxford University Press in International Studies Perspectives Vol. 17 No. 4, 445-461, 2016. Published version available from:

https://doi.org/10.1111/insp.12099

Accepted version downloaded from SOAS Research Online: http://eprints.soas.ac.uk/26058/

parties make moves to readjust and repair the relationship. Their positioning of me as 'not British' is part of this: the chairman ha shifted his understanding of me, and remade me. I too have had to remake my understanding of him, losing some of my idealization, appreciating his anger. This process carries a sense of loss: I have had to relinquish my own object and accept a different one, with significant effects on my sense of Zimbabwe and my sense of who I am. When I feel that things cannot be put quite right again, I am recognizing this loss. In the other three encounters, while I have learned about their views, I and they did far less real 'seeing' of each other during our meetings. The informal workers refused to see me at all; the young men's anger repelled and the grandmother's idealization was arguably the most distancing of all.

This is not to say that these were not significant to the research. They told me very important things about Zimbabweans' conceptions of themselves in the world - feelings of neglect and marginalization came from some; while the need to imagine and touch a sense of 'the good' emerged in others. I did not reach these insights by 'getting onto the same wavelength' or developing 'empathy' with those I interviewed, but rather by realizing and evaluating the nature of our mutual misunderstanding, the way we organized each other according to preconceived frameworks. These were difficult to cut through during the interview: it was only later as I went over them that I came to my readjustments.

My larger conclusion - which takes us back to Klein - is about loss and loneliness. Klein writes about the integration of the ego - its ability to adjust to the wider world and to acknowledge its own ambiguities and separateness - and the sense of loss and longing that come in its wake.

The realisation that the good object can never approximate to the perfection expected from the ideal one brings about de-idealisation: and even more painful is the realisation that no really ideal part of the self exists... As a patient put it to me, 'the glamour has gone'. The analysis showed that the glamour which had gone was the idealisation of the self 
This is the accepted version of an article published by Oxford University Press in International Studies Perspectives Vol. 17 No. 4, 445-461, 2016. Published version available from:

https://doi.org/10.1111/insp.12099

Accepted version downloaded from SOAS Research Online: http://eprints.soas.ac.uk/26058/

and of the object, and the loss of it led to feelings of loneliness. (Klein 1997c: 305)

The compromises researchers need to make with the 'real world' will entail a loss of intellectual excitement; and a consequent, painful sense of loneliness, as we realize that the ideal object does not exist. It is this that must be accepted as part of the project of 'learning to live with irreconcilable differences and multiple identities', as der Derian demands. One of the key insights my interviews give me is into strangeness and the othering done by each party to the other. The other is that an openness to this can lead to insight, but it is achieved through and because of otherness, not by trying to overcome it. And it involves loss and loneliness - which is about a loss within oneself, which is why it is so difficult.

\section{References}

Ackerly, Brook A, Maria Stern and Jacqui True, Eds. (2006) Feminist Methodologies for International Relations. Cambridge: Cambridge University Press.

Ackerly, Brook A. and Jacqui True. (2010) Doing Feminist Research in Political and Social Science. Basingstoke: Palgrave Macmillan.

Agar, M. (2006) An Ethnography by any other Name. Forum: Qualitative Social Research, Socialforschung 7(4): http://www.qualitativeresearch.net/index.php/fqs/article/view/177

Bourdieu, Pierre. (1996) Understanding. Theory, Culture and Society 13(2): 1737.

Alford, C. Fred. (1989) Melanie Klein and Critical Social Theory: An Account of Politics, Art and Reason Based on Her Psychoanalytic Theory. New Haven: Yale University Press. 
This is the accepted version of an article published by Oxford University Press in International Studies Perspectives Vol. 17 No. 4, 445-461, 2016. Published version available from:

https://doi.org/10.1111/insp.12099

Accepted version downloaded from SOAS Research Online: http://eprints.soas.ac.uk/26058/

Bowlby, John. (1973) Attachment and Loss, Vol 2: Separation, Anxiety and Anger. New York: Basic Books

Burgoyne, Bernard and Mary Sullivan, Eds. (1997) The Klein-Lacan Dialogues. London: Rebus Press.

Butler, Judith. (2006) Gender Trouble. London: Routledge.

Chan, Stephen. (2003) Robert Mugabe: A Life of Power and Violence. London: IB Tauris.

Crapanzano, Vincent. (2010) At the Heart of the Discipline: Critical Reflections on Fieldwork. In Emotions in the Field: The Psychology and Anthropology of Fieldwork Experience, edited by James Davies and Dimitrina Spencer. Redwood City: Stanford University Press.

Davies, James. (2010) Introduction: Emotions in the Field. In Emotions in the Field: The Psychology and Anthropology of Fieldwork Experience, edited by James Davies and Dimitrina Spencer. Redwood City: Stanford University Press.

D'Costa, Bina. (2006) Marginalized Identity: New Frontiers of Research for IR? In Feminist Methodologies for International Relations, edited by Brook Ackerly, Maria Stern and Jacqui True. Cambridge: Cambridge University Press.

Der Derian, James. (1990) The Space of International Relations: Simulation, Surveillance, and Speed. International Studies Quarterly 34 (3): 295-310.

Dwyer, S. C., and J. L. Buckle. (2009) The Space Between: On Being an InsiderOutsider in Qualitative Research. International Journal of Qualitative Methods 8 (1): 54-63.

Edkins, Jenny. (1999) Poststructuralism and International Relations: Bringing the Political Back in. London: Lynne Rienner.

Ellis, C., and L. Berger. (2003) Their Story/My Story/Our Story: Including the Researcher's Experience in Interview Research. In Inside Interviewing: New Lenses, New Concerns, edited by J. A. Holstein and J. F. Gubrium. Thousand Oaks, CA: Sage. 
This is the accepted version of an article published by Oxford University Press in International Studies Perspectives Vol. 17 No. 4, 445-461, 2016. Published version available from:

https://doi.org/10.1111/insp.12099

Accepted version downloaded from SOAS Research Online: http://eprints.soas.ac.uk/26058/

Ezzy, Douglas. (2010) Qualitative Interviewing As an Embodied Emotional Performance. Qualitative Inquiry 16 (3): 163-70.

Fanon, Franz. (1986) Black Skin, White Masks. London: Pluto Press.

Fontana, A., and J. H. Frey. (2005) The Interview: From Neutral Stance to Political Involvement. In The Sage Handbook of Qualitative Research, 3rd edition, edited by N. K. Denzin and Y. S. Lincoln. Thousand Oaks, CA: Sage.

Gallagher, Julia. (2011) Britain and Africa under Blair: In Pursuit of the Good State. Manchester: Manchester University Press.

Gallagher, Julia. (2009) Can Melanie Klein Help Us Understand Morality in IR? Suggestions for a Psychoanalytic Interpretation of Why and How States Do Good. Millennium - Journal of International Studies 38 (2): 295-316. Gallagher, Julia. (2014) Chopping the World into Bits: Object-Relations Theory and the Good Governance Norm. International Theory 6 (2): 332-49.

Glesne, C., and A. Peshkin. (1992) Becoming Qualitative Researchers: An Introduction. New York: Longman.

Jackson, Michael. (2010) From Anxiety to Method in Anthropological Fieldwork: An Appraisal of George Devereux's Enduring Ideas. In Emotions in the Field: The Psychology and Anthropology of Fieldwork Experience, edited by James Davies and Dimitrina Spencer. Redwood City: Stanford University Press.

Jacoby, Tami. (2006) From the Trenches: Dilemmas of Feminist IR Fieldwork. In Feminist Methodologies for International Relations, edited by Brook Ackerly, Maria Stern and Jacqui True. Cambridge: Cambridge University Press.

Keylor, Rheta G. (2003) Psychoanalytic Dialogues: Subjectivity, Infantile Oedipus, and Symbolization. The International Journal of Relational Perspectives 13 (2): 211-42.

Klein, Melanie. (1997a) Notes on some Schizoid Mechanisms (1946), Envy and Gratitude and other Works 1946-1963. London: Vintage: 1-24.

Klein, Melanie. (1997b) On Identification (1955), Envy and Gratitude and other Works 1946-1963. London: Vintage: 141-75.

Klein, Melanie. (1997c) On the Sense of Loneliness (1963), Envy and Gratitude and other Works 1946-1963. London: Vintage: 300-13. 
This is the accepted version of an article published by Oxford University Press in International Studies Perspectives Vol. 17 No. 4, 445-461, 2016. Published version available from:

https://doi.org/10.1111/insp.12099

Accepted version downloaded from SOAS Research Online: http://eprints.soas.ac.uk/26058/

Klein, Melanie. (1998a) The Importance of Symbol Formation in the Development of the Ego (1930), in Love, Guilt and Reparation and other Works 1921-1945. London: Vintage: 219-232.

Klein, Melanie. (1998b) A Contribution to the Theory of Intellectual Inhibition (1931) in Love, Guilt and Reparation and other Works 1921-1945. London: Vintage: 263-47.

Kristeva, Julia. (1991) Strangers to Ourselves, Trans Leon S. Roudiez. New York: Columbia University Press.

Kristeva, Julia. (2001) Melanie Klein. New York: Columbia University Press.

Michalowski, R. J. (1996) Ethnography and Anxiety: Fieldwork and Reflexivity in the Vortex of US-Cuban Relations. Qualitative Sociology 19 (1): 59-82.

Mtisi, Joseph, Munyaradzi Nyakudya, and Teresa Barnes. (2009) War in Rhodesia, 1965-1980. In Becoming Zimbabwe: a history from the precolonial period to 2008, edited by Brian Raftopoulos and Alois Mlambo. Harare, Zimbabwe: Weaver Press: 141-66.

Mudimbe, V. Y. (1988) The Invention of Africa: Gnosis, Philosophy, and the Order of Knowledge. London: James Currey.

Mullings, B. (1999) Insider or Outsider, Both or Neither: Some Dilemmas of Interviewing in a Cross-Cultural Setting. Geoforum 30: 337-50.

Rancatore, J. P. (2010) It Is Strange. Millennium - Journal of International Studies 39 (1): 65-77.

Said, Edward. (2003) Orientalism. London: Penguin.

Segal, Hanna. (2006) Introduction to the Work of Melanie Klein. London: Karnac Books.

Sultana, Farhana. (2007) Reflexivity, Positionality and Participatory Ethics: Negotiating Fieldwork Dilemmas in International Research. ACME 6 (3): 374-85.

Sylvester, Christine. (1994) Empathetic Cooperation: A Feminist Method for IR. Millennium - Journal of International Studies 23 (315): 315-34. 
This is the accepted version of an article published by Oxford University Press in International Studies Perspectives Vol. 17 No. 4, 445-461, 2016. Published version available from:

https://doi.org/10.1111/insp.12099

Accepted version downloaded from SOAS Research Online: http://eprints.soas.ac.uk/26058/

Sylvester, Christine. (2000) Producing Women and Progress in Zimbabwe:

Narratives of Identity and Work from the 1980s. Portsmouth: Heinemann.

Tanggaard, Lene. (2007) The Research Interview as Discourses Crossing Swords:

The Researcher and Apprentice on Crossing Roads. Qualitative Inquiry 13

(1): $160-76$.

Tendi, Blessing-Miles. (2010) Making History in Mugabe’s Zimbabwe: Politics, Intellectuals and the Media. Bern: Peter Lang.

Vrasti, W. (2008) The Strange Case of Ethnography and International Relations. Millennium 37 (2): 279-301.

Walker, R. B. J. (1993) Inside/Outside: International Relations as Political Theory. Cambridge: Cambridge University Press.

Watts, Carl. (2005) Killing Kith and Kin: The Viability of British Military, Intervention in Rhodesia, 1964-1965. 20 th Century British History 16 (4): $382-415$.

Winnicott (1971). Playing and Reality. London: Tavistock Publications. 